\title{
Body Composition Assessment in Patients with Periampullary Neoplasma Undergoing Pancreaticoduodenetomy and its Predictive Value for Postoperative Complications
}

\section{Zhenghua Cai}

Medical School of Nanjing University

Shanshan Xu

Medical School of Nanjing University

Yifan Zhang

Medical School of Nanjing University

\section{Yifei Yang}

Medical School of Nanjing University

Jian He

Nanjing Drum Tower Hospital, The Affiliated Hospital of Nanjing University Medical School

Yudong Qiu ( $\nabla$ yudongqiu510@nju.edu.cn )

Nanjing Drum Tower Hospital, The Affiliated Hospital of Nanjing University Medical School

\section{Research Article}

Keywords: Body composition parameters, Sarcopenia, Visceral obesity, Peri-ampullary neoplasma, Pancreaticoduodenectomy, Postoperative complications

Posted Date: October 29th, 2021

DOI: https://doi.org/10.21203/rs.3.rs-1004647/v1

License: (c) (i) This work is licensed under a Creative Commons Attribution 4.0 International License. Read Full License 


\section{Abstract}

\section{Background}

To observe body composition parameters variance in patient with periampullary neoplasmas with different clinical characteristics and assess its predictive value for postoperative complications after pancreaticoduodenectomy.

\section{Methods}

In this study, we retrospectively reviewed the clinical and image data of 144 patients with periampullary neoplasmas. The area of subcutaneous adipose tissue (SAT), visceral adipose tissue (VAT) and total abdominal muscle area (TAMA) were measured from preoperative CT images at the $3^{\text {rd }}$ lumbar vertebra level, the TAMA was normalized to stature and termed as skeleton muscle index (SMI). The perioperative and pathological data were collected.

\section{Results}

Of the included 144 patients, 80(55.6\%), 29(20.1\%) and 24(16.7\%) patients were classified as sarcopenia, visceral obesity and sarcopenic obesity. 84(58.3\%) patients were jaundiced and $28(19.4 \%) \varangle 50(34.7 \%) \rrbracket$ $66(45.8 \%)$ patients were diagnosed with benign pancreatic tumors, pancreatic cancer and non-pancreatic cancer respectively. The incidence rate of clinical postoperative pancreatic fistula(POPF) and other major complications were $38.2 \%$ and $16 \%$.In the univariate analysis, jaundiced patients experienced more weight loss and had higher nutrition risk score, the TAMA[103.1(61.1-176.7) vs 111.8(74.1198.2), $\mathrm{P}=0.021]$ and $\mathrm{SMI}(39.2 \pm 7.0$ vs $42.6 \pm 9.1, \mathrm{P}=0.012)$ were lower compared with non-jaundiced group. However, no significant difference were founded between different pathological results and it was not associated with occurrence of POPF and major complications.

\section{Conclusion}

Jaundiced patients may experience more weight loss and have lower TAMA and SMI. Body morphometric analysis of preoperative CT did not show predictive value for postoperative complications and further multicenter studies are needed.

\section{Trail registration}

Registration number冈2021-437-01.

\section{Introduction}

Incidence of biliopancreatic tumors is increasing year by year and pancreatic carcinoma shall be the second malignancy leading to death until $2030^{[1]}$. For the patients with periampullary neoplasmas such as pancreatic cancer, distal cholangiocarcinoma, duodenal tumors may firstly manifest as jaundice, 
abdominal pain and gradually the lumen of duodenal will be obstructed, patients more or less may experience dyspesia and weight loss for digestion and absorption of food being influenced. Although great improvements have been achieved in oncological and endoscopic therapy, radical surgical resection is still the first choice ${ }^{[2]}$. Pancreaticoduodenectomy is the standard procedure for the treatment of periampullary tumors, while the high incidence of postoperative complication about $30 \%-50 \%$ not only affecting patients' recovery thus extended hospitalization but also delaying the time received adjuvant therapies ${ }^{[3-4]}$.

Recently, reports have shown that preoperative body composition change can predict the surgical complication and survival of several malignant tumors, especially who are sarcopenic and visceral obesity ${ }^{\left[{ }^{[-7]}\right.}$. Given the fact that patients with pancreatic cancer may experience exocrine insufficiency and sarcopenia is common ${ }^{[8-10]}$, so we suppose that body composition change may have some relationship with postoperative complication. In this article ,we are aimed to analyze the change of body composition in patients with periampullary tumors and assess its value in predicting postoperative complications.

\section{Materials And Methods}

\section{Patients}

This retrospective studies were approved by the Health Research Ethics Board of Drum-Tower Hospital Affiliated to Nanjing University Medical School.Every patient had signed the informed consent. Patients had radiology-proven or pathology-diagnosed tumors in pancreatic head, distal biliary tract or duodenal wall and met the inclusion criteria below from December 2017 to January 2020 were included. All patients were successfully performed pancreaticoduodenectomy. The inclusion criteria were as follows: (a) patients who were treated with pancreatoduodenectomy for periampullary neoplasmas (b) patients without other active cancer; (c) patients > 18 years of age; and (d) patients who underwent preoperative enhanced CT within 1 month before operation. The exclusion criteria were as follows: (a) whose preoperative CT cannot be obtained with 1 month before operation;(b) whose clinical data are incomplete.

\section{Acquisition and analysis of CT image}

CT images were downloaded from the Picture Archiving and Communication System(PACS) of the Radiology Department including unenhanced-artery- and portal venous phase of upper abdomen. Two radiologist(Shanshan XuखYifan Zhang)analyzed the images and calculated the areas using 3D Slicer software (v. 4.10.2, www.slicer.org) and the other physician(Jian He) checked the results, both of them were blinded to the patients' information. Different tissue were distinguished by specified Hounsfield Unit and area of SAT(HU:-190 to -30),VAT(HU:-150 to -50),TAMA(HU:-29 to +150) were measured at the $3^{\text {rd }}$ lumbar vertebra level(L3) ${ }^{[11]}$ (Figure 1). The TAMA was normalized to stature by dividing the muscle area by the patient's height squared, and which is termed the skeletal muscle index (SMI= TAMA $\left(\mathrm{cm}^{2}\right) /$ height $\left(\mathrm{m}^{2}\right)$ ).Sarcopenia was defined using SMI cut-off value: $42.2 \mathrm{~cm}^{2} / \mathrm{m}^{2}$ for men and $33.9 \mathrm{~cm}^{2} / \mathrm{m}^{2}$ for 
women $^{[12]}$. Visceral obesity was defined as VFA $>136 \mathrm{~cm}^{2}$ in men and $>95 \mathrm{~cm}^{2}$ in women ${ }^{[13]}$. The cut-off value for diagnosing sarcopenic obesity was $3.2(\mathrm{VAT} / \mathrm{SMI})^{[14]}$.

\section{Clinical data collection and definition of complication}

Clinical data were collected including demographics(age, sex, pre-hospitalization weight loss, history of diabetes),preoperative nutrition risk score(NRS-2002,PG-SGA),preoperative laboratory data(hemoglobulin, transaminase, total bilirubin, albumin, prealbumin, $C$ reactive protein),data of surgery(type of surgical procedure, length of operation $₫$ volume of blood loss and transfusion),pathologic results. Postoperative complications included clinical pancreatic fistula(Grade B/ C) and surgery-related complications classified by the Clavien-Dindo classification, with major complications defined as grade $\geq \mathbb{\bigotimes}^{[15-16]}$.

\section{Statistics}

Statistical analysis was performed using SPSS 23.0 software (SPSS Inc.). Measurement data with normal distribution were presented as mean and standard deviation, and comparison between groups was analyzed using independent $t$ test. Measurement data with skewed distribution were described as median(range), and comparison between groups was analyzed using Mann-Whitney $U$ test. Count data were expressed as absolute number and percentage, and comparison between groups was analyzed using $c^{2}$ test. Univariate analysis was conducted using the $c^{2}$ test. $P<0.05$ was considered as statistics significantly.

\section{Results}

\section{Study cohort}

In this study,144 patients met the criteria above were included. The group consisted of $88(61.1 \%)$ men and $56(38.9 \%)$ women, the average age was $62.4 \pm 12$ years old. When admitted to hospital,84(58.3\%) patients were classified into jaundice group whose total bilirubin level $\geq 34.2 \mu \mathrm{mol} / \mathrm{L}$. According to the sex-specific cut-off value,80(55.6\%)patients were defined as being sarcopenic. Visceral obesity was observed in $29(20.1 \%)$ patients. When combined the two factors together, $24(16.7 \%)$ patients were diagnosed as sarcopenic obesity. All patients were performed pancreaticoduodenectomy successfully, 55(38.2\%)patients developed clinical pancreatic fistula and 23(16\%)patients developed major postoperative complications(Calvin-Dindo grade $\geq \bigotimes$ ). In the 144 patients,28(19.4\%)of them were diagnosed with pancreatic benign tumors,50(34.7\%) and 66(45.8\%) patients were diagnosed with pancreatic cancer and non-pancreatic cancer including distal cholangiocarcinoma, duodenal cancer, ampullary carcinoma respectively.

\section{Comparison of body composition according to preoperative bilirubin level}


The clinical characteristic between jaundiced and non-jaundiced patients were listed on Table 1 .Beside the variables reflects liver function were higher in jaundice group, more weight loss and higher nutrition risk score were founded compared with non-jaundiced group. The average TAMA and SMI were lower and VAT/TAMA ratio was higher in jaundiced group. Gender, BMI, SAT, VAT, rates of sarcopenia, visceral obesity and sarcopenic obesity showed no difference between the two groups.

Table 1 Comparsion between jaundiced and non-jaundiced patients

\begin{tabular}{|c|c|c|c|}
\hline Clincal data & Jaundice $\llbracket n=84 \square$ & Non-jaundice $[n=60$ [ & $P$ value \\
\hline Age & $65 \llbracket 32-82 \rrbracket$ & $62 \rrbracket 20-82 \rrbracket$ & 0.03 \\
\hline Gender[M/F[ & $52 / 32$ & $36 / 24$ & 0.817 \\
\hline Weight loss $\square \mathrm{Kg} \square$ & $4 \rrbracket 0-30 \rrbracket$ & $2.5 \rrbracket 0-15 \rrbracket$ & 0.026 \\
\hline NRS-2002 score & $4 \rrbracket 0-6 \rrbracket$ & $4 \rrbracket 0-6 \rrbracket$ & 0.009 \\
\hline PG-SGA score & 10ه3-20区 & $6 \rrbracket 1-18 \rrbracket$ & 0.001 \\
\hline $\mathrm{BMI} \mathrm{kg} / \mathrm{m}^{2} \mathrm{\square}$ & 22.6ه15.6-41.1】 & 23.3凶16.5-31.6ه & 0.884 \\
\hline ALTDU/L & 171.9凶23.9-688.9ه & 20.5ه3.3-432.6区 & 0.001 \\
\hline ASTRU/LI & 120.6冈18.7-538.7区 & 21.3凶6.3-235.8ه & 0.001 \\
\hline TBD $\mu \mathrm{mol} / \mathrm{L} \square$ & 168.8ه43.9-524.7ه & $10.7 \rrbracket 3-34 \rrbracket$ & 0.001 \\
\hline $\mathrm{DB} \square \mu \mathrm{mol} / \mathrm{L} \square$ & 120.4囚28.2-319.4区 & $2.5 \rrbracket 0.8-23.3 \rrbracket$ & 0.001 \\
\hline ALBᄆg/L口 & $36.9 \rrbracket 24.2-42.5 \rrbracket$ & $39.9 \varangle 30.5-45.4 \rrbracket$ & 0.001 \\
\hline Pro-Albロg/Lu & $140.6 \pm 52.1$ & $197.5 \pm 61.5$ & 0.001 \\
\hline $\mathrm{C}$ reactive protein & 8.3凶0.8-135『 & $4.6 \rrbracket 1.5-114.4 \rrbracket$ & 0.001 \\
\hline Diameter of MPD』mm & $3 \rrbracket 1-15 \rrbracket$ & $3 \otimes 1-25 \rrbracket$ & 0.334 \\
\hline SAT $\square \mathrm{cm}^{2} \square$ & 97.7凶28.7-259.9区 & 105.6囚32.1-194.8》 & 0.795 \\
\hline VAT $\square \mathrm{cm}^{2} \square$ & $85.2 \pm 47.6$ & $78.6 \pm 49.6$ & 0.422 \\
\hline TAMA $\square \mathrm{cm}^{2} \square$ & 103.1凶61.1-176.7】 & 111.8ه74.1-198.2】 & 0.021 \\
\hline $\mathrm{SMI} \square \mathrm{cm}^{2} / \mathrm{m}^{2} \mathrm{\square}$ & $39.2 \pm 7.0$ & $42.6 \pm 9.1$ & 0.012 \\
\hline VAT/TAMA & $2.18 \pm 1.19$ & $1.79 \pm 1.02$ & 0.043 \\
\hline Sarcopenia & $52 \llbracket 61.9 \% \bigotimes$ & $28 \otimes 46.7 \% \bigotimes$ & 0.07 \\
\hline Visceral obesity & $19 \llbracket 22.6 \% \rrbracket$ & $10 \otimes 16.7 \% \bigotimes$ & 0.38 \\
\hline Sarcopenic obesity & 14囚16.7\%】 & $10 \rrbracket 16.7 \% \rrbracket$ & 1.0 \\
\hline
\end{tabular}


*BMIखbody mass index; $\mathrm{Hb}$ :hemoglobin ;ALB:albumin;SAT:subcutaneous adipose tissue;VAT:visceral adipose tissue;TAMA:total abdominal muscle area;SMI:skeleton muscle index

\section{Comparison of body composition according to pathologic results}

The 144 patients enrolled in this study were classified into three groups as benign tumor group, pancreatic cancer(PC)group, non-pancreatic cancer group(Non-PC)according to the pathological result of the specimen. When compared the clinical data of these groups together as shown in Table 2 , only gender, serum bilirubin level and pro-albumin concentration showed statistical difference, while age, BMI, nutrition risk score, body composition parameters(SAT,VAT,TAMA,SMI)did not show any significant difference.

Table 2 Comparsion of clinical characteristics according to different pathologic results 


\begin{tabular}{|c|c|c|c|c|}
\hline Clincal data & Benign Tumor & PC & Non-PC & $P$ value \\
\hline Age & $65 \llbracket 20-77 \rrbracket$ & $62 \rrbracket 32-82 \rrbracket$ & $64 \rrbracket 36-82 \rrbracket$ & 0.111 \\
\hline Gender[M/F[ & $13 / 15$ & $37 / 13$ & $38 / 28$ & 0.041 \\
\hline Weight loss $\square \mathrm{Kg} \square$ & $2.5 \llbracket 0-15 \rrbracket$ & $4 \rrbracket 0-30 \rrbracket$ & $3 \rrbracket 0-15 \rrbracket$ & 0.46 \\
\hline NRS-2002 score & $3 \otimes 0-6 \rrbracket$ & $4 \llbracket 0-6 \rrbracket$ & $4 \rrbracket 0-6 \rrbracket$ & 0.501 \\
\hline PG-SGA score & $5.5 \llbracket 2-17 \rrbracket$ & $9.5 \llbracket 2-20 \rrbracket$ & $9.5 \otimes 1-19 \rrbracket$ & 0.389 \\
\hline $\mathrm{BMI} \mathrm{kg} / \mathrm{m}^{2} \mathrm{D}$ & 23.3凶17.7-28.4凶 & $23.2 \bigotimes 16.5-31.2 \rrbracket$ & $22.6 \bigotimes 15.6-41.1 \rrbracket$ & 0.599 \\
\hline ALTDU/L】 & $20.5 \llbracket 3.3-452.8 \rrbracket$ & $125.8 \rrbracket 8.3-688.9 \rrbracket$ & 134.5囚7.9-454.1》 & 0.087 \\
\hline ASTRU/Lם & $23.5 \rrbracket 6.3-359.9 \rrbracket$ & $88.7 \rrbracket 9.5-454.2 \rrbracket$ & $96 \rrbracket 8.5-538.7 \rrbracket$ & 0.053 \\
\hline $\mathrm{TB} \square \mu \mathrm{mol} / \mathrm{L} \square$ & 10.1区3-137.9凶 & $113.4 \rrbracket 4.3-413.8 \rrbracket$ & 141.9凶5.9-524.7》 & 0.049 \\
\hline $\mathrm{DB} \square \mu \mathrm{mol} / \mathrm{L} \square$ & 2.3凶1-99.2邓 & 85.1区0.8-287.7区 & $107.9 \rrbracket 0.8-319.4 \rrbracket$ & 0.038 \\
\hline ALBᄆg/L】 & 40囚33.1-44】 & $38.5 \rrbracket 29.4-45.4 \rrbracket$ & $36.8 \rrbracket 24.2-42.2 \rrbracket$ & 0.036 \\
\hline Pro-Alb[g/Lם & $193.3 \pm 65.6$ & $163.2 \pm 53.6$ & $152.8 \pm 64.7$ & 0.008 \\
\hline$C$ reactive protein & $4.8 \rrbracket 1.7-114.4 \rrbracket$ & 5.3ه1.5-102.7ه & 7.2区0.8-135》 & 0.299 \\
\hline Diameter of MPDImm[ & $3 \rrbracket 1-25 \rrbracket$ & $4 \rrbracket 1-15 \rrbracket$ & $3 \rrbracket 1-12 \rrbracket$ & 0.38 \\
\hline SATD $\mathrm{cm}^{2} \square$ & 86.8ه34.5-194.8ه & 109.1凶28.7-259.9ه & $99.2 \rrbracket 29.6-236.8 \rrbracket$ & 0.565 \\
\hline VATपcm² $\square$ & $74.1 \pm 51.9$ & $79.4 \pm 46.2$ & $88.3 \pm 48.4$ & 0.149 \\
\hline TAMA $\square \mathrm{cm}^{2} \square$ & 113.7ه75.1-172.9ه & 101.4ه71.9-198.2】 & 107.1凶61.1-163】 & 0.159 \\
\hline $\mathrm{SMI} \square \mathrm{cm}^{2} / \mathrm{m}^{2} \square$ & $42.4 \llbracket 29.1-63.5 \rrbracket$ & $38.5 \rrbracket 27.2-71.9 \rrbracket$ & $40.1 \rrbracket 25.4-57.6 \rrbracket$ & 0.233 \\
\hline VAT/TAMA & $1.67 \pm 0.99$ & $2.21 \pm 1.22$ & $2.03 \pm 1.11$ & 0.141 \\
\hline Sarcopenia & $17 \rrbracket 60.7 \% \rrbracket$ & $25 \llbracket 50 \% \rrbracket$ & $38 \rrbracket 57.6 \% \rrbracket$ & 0.596 \\
\hline Visceral obesity & $2 \rrbracket 7.1 \% \bigotimes$ & $11 \llbracket 22 \% \rrbracket$ & $16 \rrbracket 24.2 \% \rrbracket$ & 0.154 \\
\hline Sarcopenic obesity & $3 \rrbracket 10.7 \% \rrbracket$ & 8囚16\%】 & $13 \rrbracket 13.7 \% \rrbracket$ & 0.558 \\
\hline
\end{tabular}

PC: pancreatic carcinoma; Non-PC including distal cholangiocarcinoma, cancer of ampulla and duodenal carcinoma.

\section{Analysis of related variables of postoperative complications}

In the univariate analysis, several related factors that may predict POPF and major complication are shown in Table 3 and Table 4. Between patients with and without POPF, only the diameter of MPD 
showed difference significantly. Between patients with and without major complications, only the preoperative WBC counts differed significantly. Contrary to our previous hypothesis, body composition parameters(SAT,VAT,TAMA,SMI)did not show any value in predicting POPF and major complications.

\section{Table 3 univariate analysis of potential factors associated with POPF}




\begin{tabular}{|c|c|c|c|}
\hline & POPF grade B/C口 & & $P$ value \\
\hline Clinical data & With POPFIn=55ם & Without POPF $\square=89 \square$ & \\
\hline Age & $64.5 \llbracket 31-82 \rrbracket$ & $65 \rrbracket 20-82 \rrbracket$ & 0.492 \\
\hline Gender[M/F[ & $33 / 22$ & $55 / 34$ & 0.83 \\
\hline Weight loss $\square \mathrm{Kg} \square$ & $3 \llbracket 0-15 \rrbracket$ & $3 \bowtie 0-30 \rrbracket$ & 0.417 \\
\hline NRS-2002 score & $4 \rrbracket 0-6 \rrbracket$ & $4 \llbracket 0-6 \rrbracket$ & 0.409 \\
\hline PG-SGA score & $8 \rrbracket 2-20 \rrbracket$ & $9 \otimes 1-17 \rrbracket$ & 0.544 \\
\hline $\mathrm{BMI} \square \mathrm{kg} / \mathrm{m}^{2} \mathrm{Q}$ & $23.7 \pm 3.6$ & $22.9 \pm 3.2$ & 0.156 \\
\hline WBC $\square \times 10^{9} / \mathrm{L} \square$ & $5.8 \pm 1.9$ & $5.6 \pm 1.9$ & 0.521 \\
\hline $\mathrm{Hb} \square \mathrm{g} / \mathrm{L} \square$ & $122.2 \pm 18.1$ & $122.3 \pm 15.6$ & 0.969 \\
\hline Pltచx $10^{9} / \mathrm{L} \square$ & $222 \rrbracket 84-436 \rrbracket$ & $215 \rrbracket 55-516 \rrbracket$ & 0.474 \\
\hline ALBロg/L】 & $37.9 \rrbracket 25.6-44 \rrbracket$ & $38 \llbracket 24.2-45.4 \rrbracket$ & 0.844 \\
\hline Pro-Alb!g/L $]$ & $166.8 \pm 70.5$ & $162.8 \pm 57.7$ & 0.711 \\
\hline $\mathrm{C}$ reactive protein & $5.5 \rrbracket 0.8-135 \rrbracket$ & $5.4 \rrbracket 1.3-113.4 \rrbracket$ & 0.577 \\
\hline SATDcm ${ }^{2} \square$ & 102.7凶35.5-236.8\ & $99.3 \rrbracket 28.7-259.9 \rrbracket$ & 0.623 \\
\hline VAT $\square \mathrm{cm}^{2} \square$ & $88.6 \pm 47.2$ & $78.7 \pm 48.9$ & 0.235 \\
\hline TAMA $\square \mathrm{cm}^{2} \square$ & $107.3 \pm 27.2$ & $110.6 \pm 25.3$ & 0.472 \\
\hline $\mathrm{SMI} \square \mathrm{cm}^{2} / \mathrm{m}^{2} \square$ & $39.8 \pm 8.4$ & $41.2 \pm 7.8$ & 0.31 \\
\hline VAT/TAMA & $2.25 \pm 1.21$ & $1.89 \pm 1.08$ & 0.065 \\
\hline Sarcopenia & $34 \llbracket 61.8 \% \rrbracket$ & $46 \rrbracket 51.7 \% \rrbracket$ & 0.234 \\
\hline Visceral obesity & $9 \otimes 16.3 \% \square$ & $20 \rrbracket 22.5 \% \rrbracket$ & 0.375 \\
\hline Sarcopenic obesity & $5 \otimes 9.1 \% \bigotimes$ & $19 \llbracket 21.3 \% \rrbracket$ & 0.055 \\
\hline Diameter of MPDImmL & $3 \rrbracket 1-8.6 \rrbracket$ & $4 \llbracket 1-25 \rrbracket$ & 0.027 \\
\hline Length of operation $\llbracket \mathrm{min} \square$ & $367.5 \rrbracket 230-800 \rrbracket$ & $380(225-745)$ & 0.866 \\
\hline Blood loss $[\mathrm{ml} \mid \mathrm{a}$ & $450 \rrbracket 100-3600 \rrbracket$ & $500 \otimes 50-3200 \otimes$ & 0.404 \\
\hline Blood transfusion[ml] & $0 \otimes 0-4100 \rrbracket$ & 0ه0-1925》 & 0.866 \\
\hline
\end{tabular}

Table 4 univariate analysis of potential factors associated with major complications 


\begin{tabular}{|c|c|c|c|}
\hline \multirow[b]{2}{*}{ Clinical data } & \multicolumn{2}{|c|}{ Major complications $\square$ Calvin-Dindo grade $\geq 3 \square$} & \multirow[t]{2}{*}{$P$ value } \\
\hline & with $n n=23 \square$ & without $\square n=121 \square$ & \\
\hline Age & $64 \rrbracket 44-80 \rrbracket$ & $65 \llbracket 20-82 \rrbracket$ & 0.902 \\
\hline Gender[M/F[ & $17 / 6$ & $71 / 50$ & 0.169 \\
\hline Weight loss $\square \mathrm{Kg} \square$ & $3 \llbracket 0-15 \rrbracket$ & $3 \rrbracket 0-30 \rrbracket$ & 1.0 \\
\hline NRS-2002 score & $4 \rrbracket 0-6 \rrbracket$ & $4 \otimes 0-6 \rrbracket$ & 0.282 \\
\hline PG-SGA score & $8 \rrbracket 2-19 \rrbracket$ & $9 \rrbracket 1-20 \rrbracket$ & 0.522 \\
\hline $\mathrm{BM} I \mathrm{~kg} / \mathrm{m}^{2} \mathrm{\square}$ & $23.3 \pm 3.1$ & $23.1 \pm 3.4$ & 0.891 \\
\hline WBC $\times 10^{9} / \mathrm{L \square}$ & $6.3 \rrbracket 3.3-10.2 \rrbracket$ & $5.1 \rrbracket 2.4-12.3 \rrbracket$ & 0.015 \\
\hline $\mathrm{Hb} \square \mathrm{g} / \mathrm{L} \square$ & $124.5 \pm 19.1$ & $121.9 \pm 16.1$ & 0.486 \\
\hline Plt $\times 10^{9} / \mathrm{LD}$ & $232 \rrbracket 91-422 \rrbracket$ & $215.5 \llbracket 59-516 \rrbracket$ & 0.256 \\
\hline ALBDg/L口 & $36.7 \rrbracket 25.6-44 \rrbracket$ & $37.9 \llbracket 24.2-45.4 \rrbracket$ & 0.561 \\
\hline Pro-Alb!g/L $\square$ & $166.6 \pm 77.1$ & $163.8 \pm 59.9$ & 0.845 \\
\hline $\mathrm{C}$ reactive protein & $5.5 \rrbracket 0.8-84 \rrbracket$ & $5.4 \rrbracket 1.3-135 \rrbracket$ & 0.733 \\
\hline SATGcm² & $103.1 \rrbracket 29.6-188.2 \rrbracket$ & $98.7 \rrbracket 28.7-259.9 \rrbracket$ & 0.653 \\
\hline VATI $\mathrm{cm}^{2} \square$ & $82.9 \pm 52.9$ & $82.4 \pm 47.7$ & 0.956 \\
\hline 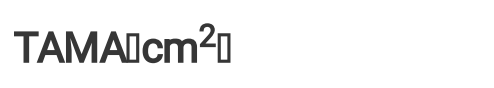 & 101.2ه72.5-172.9邓 & 107.3ه61.1-198.2】 & 0.705 \\
\hline $\mathrm{SM} \square \mathrm{cm}^{2} / \mathrm{m}^{2} \square$ & $40.3 \pm 9.6$ & $40.7 \pm 7.8$ & 0.805 \\
\hline VAT/TAMA & $2.15 \pm 1.52$ & $2.0 \pm 1.05$ & 0.56 \\
\hline Sarcopenia & $15 \rrbracket 65.2 \% \square$ & $65 \llbracket 53.7 \% \rrbracket$ & 0.309 \\
\hline Visceral obesity & $3 \otimes 13 \% \rrbracket$ & $26 \rrbracket 21.5 \% \bigotimes$ & 0.57 \\
\hline Sarcopenic obesity & $1 \rrbracket 4.3 \% \rrbracket$ & $23 \rrbracket 19 \% \rrbracket$ & 0.125 \\
\hline Diameter of MPD[mm & $3 \otimes 1-8.6 \rrbracket$ & $3 \rrbracket 1-25 \rrbracket$ & 0.943 \\
\hline Length of operation $\llbracket \mathrm{min} \square$ & $395.2 \pm 122.1$ & $391.6 \pm 98.9$ & 0.878 \\
\hline Blood loss $[\mathrm{ml}[\mathrm{Z}$ & $500 \rrbracket 100-3600 \rrbracket$ & $400 \rrbracket 50-3200 \rrbracket$ & 0.585 \\
\hline Blood transfusion $\square m \mid[$ & $300 \rrbracket 0-3375 \rrbracket$ & $0 \rrbracket 0-4100 \rrbracket$ & 0.374 \\
\hline
\end{tabular}

\section{Discussion}


In this retrospective study, it revealed that jaundiced patients with periampullary tumors is more prone to loss weight and have higher nutrition risk scores. when introduced CT images as an evaluation modality, it showed significant difference between jaundice and non-jaundice patients in TAMA and SMI. While morphometric parameters such as sarcopenia and visceral obesity were not predictive factors of POPF and other major complications after pancreaticoduodenectomy.

Recent years, the incidence of biliopancreatic carcinoma is increasing and surgical resection still remains the curative therapy. Nevertheless, the high incidence of morbidity and mortality about $40 \%$ and $5 \%$ respectively threaten patients' recovery. It had been thought that perioperative management and the TNMstage of tumor were vital factors affected the recovery and prognosis ${ }^{[17-18]}$, but it is gradually drawing attention that patient individual characteristic such as combined-disease, nutritional status may play an important role as well. BMI, nutrition risk score(NRS-2002,PG-SGA score) are the common nutrition appraisal tools, but BMI reflects the overall nutrition status and might cause some bias. For example, an obese patient may have excessive adipose accumulation while the muscle may atrophy or be infiltrated by fat ${ }^{[19-20]}$. Our institution also conducted body composition analysis by bioelectrical impedance(BIA), but the result maybe inconsistent ${ }^{[21-22]}$. Nowadays, CT acts as a new tool assessing the body composition is gaining its popularity for its accuracy and reliability ${ }^{[23]}$. Several study on hepatocellular carcinoma, gastric and colorectal carcinoma showed that preoperative sarcopenia and visceral obesity have significant impact on postoperative complication and overall survival rate ${ }^{[6,24]}$.

Jaundice is the common symptom of bilio-pancreatic disease for the outlet of the bile tract is obstructed, dyspepsia and weight loss were general complaints of these patients as well. Clugston et al's ${ }^{[25]}$ study showed that jaundiced group were significantly malnourished and thus the surgery-related mortality and duration of stay after intervention were differed from non-jaundiced group, which was similar to our results in some extents. We further evaluated the nutrition status of the included patients according to the area of muscle and adipose tissue at the L3 vertebral body level. The TAMA and SMI were higher in nonjaundiced group and was consistent with its higher nutrition risk score. Several points may account for it. First of all, bile is an important substance to promote fat digestion, insufficient production of bile can lead to steatorrhea and vitamin deficiency ${ }^{[26]}$. Secondly, dysfunction of kupffer cell, proliferation and translocation of gut normal bacterium and accumulation of bacterium in bile make the body be in inflammatory state and prone to suffer from cholangitis, which leads to the increased consumption of protein ${ }^{[27-28]}$. Last but not least, impaired hepatocellular function results in insufficient protein synthesis, gluconeogenesis, and ketogenesis disorders ${ }^{[29]}$. Although there is no consensus on routine biliary drainage before operation, it is wise to adopt biliary drainage and reuse to maintain the normal enterohepatic circulation in malnourished patients and morphometric parameters from CT images could be a reference.

When the body composition parameters of three different pathologic types of periampullary tumors classified as benign tumors, pancreatic carcinoma and non-pancreatic carcinoma were compared, no significant difference were observed. Pancreas is the exocrine organ of great importance through 
secreting several enzymes assisting the digestion, and more than $50 \%$ of patients with pancreatic ductal carcinoma suffered from weight loss compared to the percentage about $10 \%$ in ampullary cancer group ${ }^{[30-31]}$. Causes of high incidence of weight loss in pancreatic carcinoma group can be attributed to tissue-fibrosis, exocrine and endocrine insufficiency, obstruction of duodenum and cancer induced cachexia $^{[32-33]}$. Contrary to the original hypothesis, patients with resectable pancreatic carcinoma experienced less muscle loss compared with unresectable or borderline resectable group, which had been indentified in Sandini et al's study that loss of muscle tissue is associated with tumor resectability ${ }^{[34]}$.

In the univariate analysis, diameter of MPD is the only factor associated with POPF which has been validated in previous study ${ }^{[35]}$. However, out of expectation, we did not find sarcopenia, visceral obesity and sarcopenic obesity impact the morbidity. It was doubtful that whether sarcopenia relate to the POPF. Kosei et al's[36] study showed that sarcopenia was the risk factor of postoperative infectious complications for the cancer impaired immune function, but more research insisted that sarcopenia alone may not predict the clinical outcome in that it only reflects the depleted mass not the quality of muscle $e^{[37-38]}$. A clinical prospective study conducted by Huang et al proposed sarcopenia should be defined as low muscle mass, low strength and physical performance ${ }^{[39]}$.In their results, low muscle mass(OR 3.853, 95\% $\mathrm{Cl} 1.446-10.263, \mathrm{P}=0.007$ )(be regarded as sarcopenia in most study)and sarcopenia(OR 4.758, 95\% $\mathrm{Cl} 1.627-13.917, \mathrm{P}=0.004$ )were independent risk factors for the postoperative morbidity, while sarcopenia had better predictive power when the two functional tests were added.

It had been identified in a series of studies that excessive visceral not subcutaneous adipose tissue was the risk factor of postoperative morbidities. On the one hand, increased adipose mass may add extra difficulties to the operation ${ }^{[41-42]}$, on the other hand, visceral adipose tissue is considered to be an active organ producing some cytokines and pro-inflammatory adipocytokines such as leptin, TNF-a, IL-1, and IL6 leading to the delayed healing of wound especially the pancreaticoenteric anastomosis ${ }^{[43-45]}$. Nevertheless, The results of this study were inconsistent with our expectations that visceral obesity or sarcopenic obesity did not impact the outcome. It can be attributed to the indefinite cutoff point of visceral obesity and sarcopenic obesity between different population or nations, so further studies need to be conducted ${ }^{[46]}$.

The present study has various limitations. First, it was a retrospective study based on available data, so we can not evaluate the function of muscle such as handgrip strength and 6-m usual gait speed, which was adopted in limited research and further prospective studies of functional tests ought to be conducted. Second, the study was a small study from a single center, to validated the value of body composition parameters on complications, multicenter researches are indispensable.

In conclusion, the results of our study showed that jaundiced patients may experience more weight loss in the early stage of disease, while the parameters of body composition such as sarcopenia and visceral 
obesity did not show significant predictive value on postoperative complications and further multicenter studies are needed.

\section{Abbreviations}

SAT:subcutaneous adipose tissue;VAT: visceral adipose tissue ;TAMA:total abdominal muscle area;SMI:skeleton muscle index;POPF:postoperative pancreatic fistula;BMIखbody mass index; $\mathrm{Hb}$ :hemoglobin ;ALB:albumin;PC: pancreatic carcinoma.

$$
>
$$

\section{Declarations}

\section{Ethics approval and consent to participate}

All procedures performed in studies involving human participants were in accordance with the ethical standards of the institutional and/or national research committee and with the 1964 Helsinki declaration and its later amendments or comparable ethical standards (Trial registration number $2021-437-01$ ).Every patient had signed the informed consent.

\section{Consent for publication}

Not applicable.

\section{Availability of data and materials}

The datasets used and/or analysed during the current study are available from YD Qiu and J He on reasonable request.

\section{Competing interests}

The authors declare that they have no conflict of interest.

\section{Funding}

No funding.

\section{Authors' contributions}

QYD and HJ contributed to the conception of the study.XSS and ZYFconducted the CT image analysis and checked by HJ.YYF contributed to the data analysis.CZH performed the data analysis and wrote the manuscript.

All authors have read and approved the manuscript. 
Correspondence to Jian He and Yudong Qiu.

\section{Acknowledgements}

Not applicable.

\section{References}

1. Rahib L, Smith BD, Aizenberg R, Rosenzweig AB, Fleshman JM, Matrisian LM. Projecting cancer incidence and deaths to 2030: the unexpected burden of thyroid, liver, and pancreas cancers in the United States. Cancer Res. 2014 Jun 1;74(11):2913-21.

2. Tempero MA, Malafa MP, Al-Hawary M, Asbun H, Bain A, Behrman SW, Benson AB 3rd, Binder E, Cardin DB, Cha C, Chiorean EG, Chung V, Czito B, Dillhoff M, Dotan E, Ferrone CR, Hardacre J, Hawkins WG, Herman J, Ko AH, Komanduri S, Koong A, LoConte N, Lowy AM, Moravek C, Nakakura EK, O'Reilly EM, Obando J, Reddy S, Scaife C, Thayer S, Weekes CD, Wolff RA, Wolpin BM, Burns J, Darlow S. Pancreatic Adenocarcinoma, Version 2.2017, NCCN Clinical Practice Guidelines in Oncology. J Natl Compr Canc Netw. 2017 Aug;15(8):1028-1061.

3. Kawaida H, Kono H, Hosomura N, Amemiya H, Itakura J, Fujii H, Ichikawa D. Surgical techniques and postoperative management to prevent postoperative pancreatic fistula after pancreatic surgery. World J Gastroenterol. 2019 Jul 28;25(28):3722-3737.

4. Karim SAM, Abdulla KS, Abdulkarim QH, Rahim FH. The outcomes and complications of pancreaticoduodenectomy (Whipple procedure): Cross sectional study. Int J Surg. 2018 Apr;52:383387.

5. Kamo N, Kaido T, Hamaguchi Y, Okumura S, Kobayashi A, Shirai H, Yao S, Yagi S, Uemoto S. Impact of sarcopenic obesity on outcomes in patients undergoing living donor liver transplantation. Clin Nutr. 2019 Oct;38(5):2202-2209.

6. Zhuang CL, Huang DD, Pang WY, Zhou CJ, Wang SL, Lou N, Ma LL, Yu Z, Shen X. Sarcopenia is an Independent Predictor of Severe Postoperative Complications and Long-Term Survival After Radical Gastrectomy for Gastric Cancer: Analysis from a Large-Scale Cohort. Medicine (Baltimore). 2016 Mar;95(13):e3164.

7. Wang SL, Ma LL, Chen XY, Zhou DL, Li B, Huang DD, Yu Z, Shen X, Zhuang CL. Impact of visceral fat on surgical complications and long-term survival of patients with gastric cancer after radical gastrectomy. Eur J Clin Nutr. 2018 Mar;72(3):436-445.

8. Vujasinovic M, Valente R, Del Chiaro M, Permert J, Löhr JM. Pancreatic Exocrine Insufficiency in Pancreatic Cancer. Nutrients. 2017 Feb 23;9(3):183. doi: 10.3390/nu9030183. PMID: 28241470; PMCID: PMC5372846.

9. Tan BH, Birdsell LA, Martin L, Baracos VE, Fearon KC. Sarcopenia in an overweight or obese patient is an adverse prognostic factor in pancreatic cancer. Clin Cancer Res. 2009 Nov 15;15(22):6973-9. 
10. Chan MY, Chok KSH. Sarcopenia in pancreatic cancer - effects on surgical outcomes and chemotherapy. World J Gastrointest Oncol. 2019 Jul 15;11(7):527-537.

11. Mourtzakis M, Prado CM, Lieffers JR, Reiman T, McCargar LJ, Baracos VE. A practical and precise approach to quantification of body composition in cancer patients using computed tomography images acquired during routine care. Appl Physiol Nutr Metab. 2008 Oct;33(5):997-1006.

12. Choi Y, Oh DY, Kim TY, Lee KH, Han SW, Im SA, Kim TY, Bang YJ. Skeletal Muscle Depletion Predicts the Prognosis of Patients with Advanced Pancreatic Cancer Undergoing Palliative Chemotherapy, Independent of Body Mass Index. PLoS One. 2015 Oct 5;10(10):e0139749.

13. Kim HI, Kim JT, Yu SH, Kwak SH, Jang HC, Park KS, Kim SY, Lee HK, Cho YM. Gender differences in diagnostic values of visceral fat area and waist circumference for predicting metabolic syndrome in Koreans. J Korean Med Sci. 2011 Jul;26(7):906-13.

14. Pecorelli N, Carrara G, De Cobelli F, Cristel G, Damascelli A, Balzano G, Beretta L, Braga M. Effect of sarcopenia and visceral obesity on mortality and pancreatic fistula following pancreatic cancer surgery. Br J Surg. 2016 Mar;103(4):434-42.

15. Bassi C, Marchegiani G, Dervenis C, Sarr M, Abu Hilal M, Adham M, Allen P, Andersson R, Asbun HJ, Besselink MG, Conlon K, Del Chiaro M, Falconi M, Fernandez-Cruz L, Fernandez-Del Castillo C, Fingerhut A, Friess H, Gouma DJ, Hackert T, Izbicki J, Lillemoe KD, Neoptolemos JP, Olah A, Schulick R, Shrikhande SV, Takada T, Takaori K, Traverso W, Vollmer CR, Wolfgang CL, Yeo CJ, Salvia R, Buchler M; International Study Group on Pancreatic Surgery (ISGPS). The 2016 update of the International Study Group (ISGPS) definition and grading of postoperative pancreatic fistula: 11 Years After. Surgery. 2017 Mar;161(3):584-591.

16. Clavien PA, Barkun J, de Oliveira ML, Vauthey JN, Dindo D, Schulick RD, de Santibañes E, Pekolj J, Slankamenac K, Bassi C, Graf R, Vonlanthen R, Padbury R, Cameron JL, Makuuchi M. The ClavienDindo classification of surgical complications: five-year experience. Ann Surg. 2009 Aug;250(2):18796.

17. Kiyochi H, Matsukage S, Nakamura T, Ishida N, Takada Y, Kajiwara S. Pathologic Assessment of Pancreatic Fibrosis for Objective Prediction of Pancreatic Fistula and Management of Prophylactic Drain Removal After Pancreaticoduodenectomy. World J Surg. 2015 Dec;39(12):2967-74.

18. Pawlik TM, Gleisner AL, Cameron JL, Winter JM, Assumpcao L, Lillemoe KD, Wolfgang C, Hruban RH, Schulick RD, Yeo CJ, Choti MA. Prognostic relevance of lymph node ratio following pancreaticoduodenectomy for pancreatic cancer. Surgery. 2007 May;141(5):610-8.

19. Sandini M, Bernasconi DP, Fior D, Molinelli M, Ippolito D, Nespoli L, Caccialanza R, Gianotti L. A high visceral adipose tissue-to-skeletal muscle ratio as a determinant of major complications after pancreatoduodenectomy for cancer. Nutrition. 2016 Nov-Dec;32(11-12):1231-7.

20. De Lorenzo A, Bianchi A, Maroni P, lannarelli A, Di Daniele N, lacopino L, Di Renzo L. Adiposity rather than BMI determines metabolic risk. Int J Cardiol. 2013 Jun 5;166(1):111-7.

21. Wigmore SJ, Barber MD, Ross JA, Tisdale MJ, Fearon KC. Effect of oral eicosapentaenoic acid on weight loss in patients with pancreatic cancer. Nutr Cancer. 2000;36(2):177-84. 
22. Barber MD, McMillan DC, Preston T, Ross JA, Fearon KC. Metabolic response to feeding in weightlosing pancreatic cancer patients and its modulation by a fish-oil-enriched nutritional supplement. Clin Sci (Lond). 2000 Apr;98(4):389-99.

23. Schröder FF, de Graaff F, Bouman DE, Brusse-Keizer M, Slump KH, Klaase JM. The Preoperative CTScan Can Help to Predict Postoperative Complications after Pancreatoduodenectomy. Biomed Res Int. 2015;2015:824525.

24. Peng PD, van Vledder MG, Tsai S, de Jong MC, Makary M, Ng J, Edil BH, Wolfgang CL, Schulick RD, Choti MA, Kamel I, Pawlik TM. Sarcopenia negatively impacts short-term outcomes in patients undergoing hepatic resection for colorectal liver metastasis. HPB (Oxford). 2011 Jul;13(7):439-46.

25. Clugston A, Paterson HM, Yuill K, Garden OJ, Parks RW. Nutritional risk index predicts a high-risk population in patients with obstructive jaundice. Clin Nutr. 2006 Dec;25(6):949-54.

26. Wang L, Yu WF. Obstructive jaundice and perioperative management. Acta Anaesthesiol Taiwan. 2014 Mar;52(1):22-9.

27. Cakmakci M, Tirnaksiz B, Hayran M, Belek S, Gürbüz T, Sayek I. Effects of obstructive jaundice and external biliary diversion on bacterial translocation in rats. Eur J Surg. 1996 Jul;162(7):567-71.

28. Reynolds JV, Murchan P, Leonard N, Clarke P, Keane FB, Tanner WA. Gut barrier failure in experimental obstructive jaundice. J Surg Res. 1996 Apr;62(1):11-6.

29. Foschi D, Cavagna G, Callioni F, Morandi E, Rovati V. Hyperalimentation of jaundiced patients on percutaneous transhepatic biliary drainage. Br J Surg. 1986 Sep;73(9):716-9.

30. Olson SH, Xu Y, Herzog K, Saldia A, DeFilippis EM, Li P, Allen PJ, O'Reilly EM, Kurtz RC. Weight Loss, Diabetes, Fatigue, and Depression Preceding Pancreatic Cancer. Pancreas. 2016 Aug;45(7):986-91.

31. Gaspar B, Beuran M, Paun S, Ganescu R, Hostiuc S, Negoi I. Current strategies in the therapeutic approach for adenocarcinoma of the ampulla of Vater.[J] .J Med Life, 2013, 6: 260-5.

32. Gilliland TM, Villafane-Ferriol N, Shah KP, Shah RM, Tran Cao HS, Massarweh NN, Silberfein EJ, Choi EA, Hsu C, McElhany AL, Barakat O, Fisher W, Van Buren G. Nutritional and Metabolic Derangements in Pancreatic Cancer and Pancreatic Resection. Nutrients. 2017 Mar 7;9(3):243.

33. Hendifar AE, Petzel MQB, Zimmers TA, Denlinger CS, Matrisian LM, Picozzi VJ, Rahib L; Precision Promise Consortium. Pancreas Cancer-Associated Weight Loss. Oncologist. 2019 May;24(5):691701.

34. Sandini M, Patino M, Ferrone CR, Alvarez-Pérez CA, Honselmann KC, Paiella S, Catania M, Riva L, Tedesco G, Casolino R, Auriemma A, Salandini MC, Carrara G, Cristel G, Damascelli A, Ippolito D, D'Onofrio M, Lillemoe KD, Bassi C, Braga M, Gianotti L, Sahani D, Fernández-Del Castillo C. Association Between Changes in Body Composition and Neoadjuvant Treatment for Pancreatic Cancer. JAMA Surg. 2018 Sep 1;153(9):809-815.

35. Sugimoto M, Takahashi S, Kojima M, Kobayashi T, Gotohda N, Konishi M. In Patients with a Soft Pancreas, a Thick Parenchyma, a Small Duct, and Fatty Infiltration Are Significant Risks for Pancreatic Fistula After Pancreaticoduodenectomy. J Gastrointest Surg. 2017 May;21(5):846-854. 
36. Takagi K, Yoshida R, Yagi T, Umeda Y, Nobuoka D, Kuise T, Fujiwara T. Radiographic sarcopenia predicts postoperative infectious complications in patients undergoing pancreaticoduodenectomy. BMC Surg. 2017 May 26;17(1):64.

37. Peng P, Hyder O, Firoozmand A, Kneuertz P, Schulick RD, Huang D, Makary M, Hirose K, Edil B, Choti MA, Herman J, Cameron JL, Wolfgang CL, Pawlik TM. Impact of sarcopenia on outcomes following resection of pancreatic adenocarcinoma. J Gastrointest Surg. 2012 Aug;16(8):1478-86.

38. Jang M, Park HW, Huh J, Lee JH, Jeong YK, Nah YW, Park J, Kim KW. Predictive value of sarcopenia and visceral obesity for postoperative pancreatic fistula after pancreaticoduodenectomy analyzed on clinically acquired CT and MRI. Eur Radiol. 2019 May;29(5):2417-2425.

39. Huang DD, Wang SL, Zhuang CL, Zheng BS, Lu JX, Chen FF, Zhou CJ, Shen X, Yu Z. Sarcopenia, as defined by low muscle mass, strength and physical performance, predicts complications after surgery for colorectal cancer. Colorectal Dis. 2015 Nov;17(11):0256-64.

40. Yamane H, Abe T, Amano H, Hanada K, Minami T, Kobayashi T, Fukuda T, Yonehara S, Nakahara M, Ohdan H, Noriyuki T. Visceral Adipose Tissue and Skeletal Muscle Index Distribution Predicts Severe Pancreatic Fistula Development After Pancreaticoduodenectomy. Anticancer Res. 2018 Feb;38(2):1061-1066.

41. Yamada H, Kojima K, Inokuchi M, Kawano T, Sugihara K. Effect of obesity on technical feasibility and postoperative outcomes of laparoscopy-assisted distal gastrectomy-comparison with open distal gastrectomy. J Gastrointest Surg. 2008 Jun;12(6):997-1004.

42. Makino H, Kunisaki C, Akiyama H, Ono HA, Kosaka T, Takagawa R, Nagano Y, Fujii S, Shimada H. Effect of obesity on intraoperative bleeding volume in open gastrectomy with D2 lymph-node dissection for gastric cancer. Patient Saf Surg. 2008 Apr 24;2:7.

43. Tilg Herbert,Moschen Alexander R,Adipocytokines: mediators linking adipose tissue, inflammation and immunity.[J] .Nat Rev Immunol, 2006, 6: 772-83.

44. Jia SH, Li Y, Parodo J, Kapus A, Fan L, Rotstein OD, Marshall JC. Pre-B cell colony-enhancing factor inhibits neutrophil apoptosis in experimental inflammation and clinical sepsis. J Clin Invest. 2004 May;113(9):1318-27.

45. Bekri S, Gual P, Anty R, Luciani N, Dahman M, Ramesh B, lannelli A, Staccini-Myx A, Casanova D, Ben Amor I, Saint-Paul MC, Huet PM, Sadoul JL, Gugenheim J, Srai SK, Tran A, Le Marchand-Brustel Y. Increased adipose tissue expression of hepcidin in severe obesity is independent from diabetes and NASH. Gastroenterology. 2006 Sep;131(3):788-96.

46. Choi MH, Yoon SB, Lee K, Song M, Lee IS, Lee MA, Hong TH, Choi MG. Preoperative sarcopenia and post-operative accelerated muscle loss negatively impact survival after resection of pancreatic cancer. J Cachexia Sarcopenia Muscle. 2018 Apr;9(2):326-334.

\section{Figures}




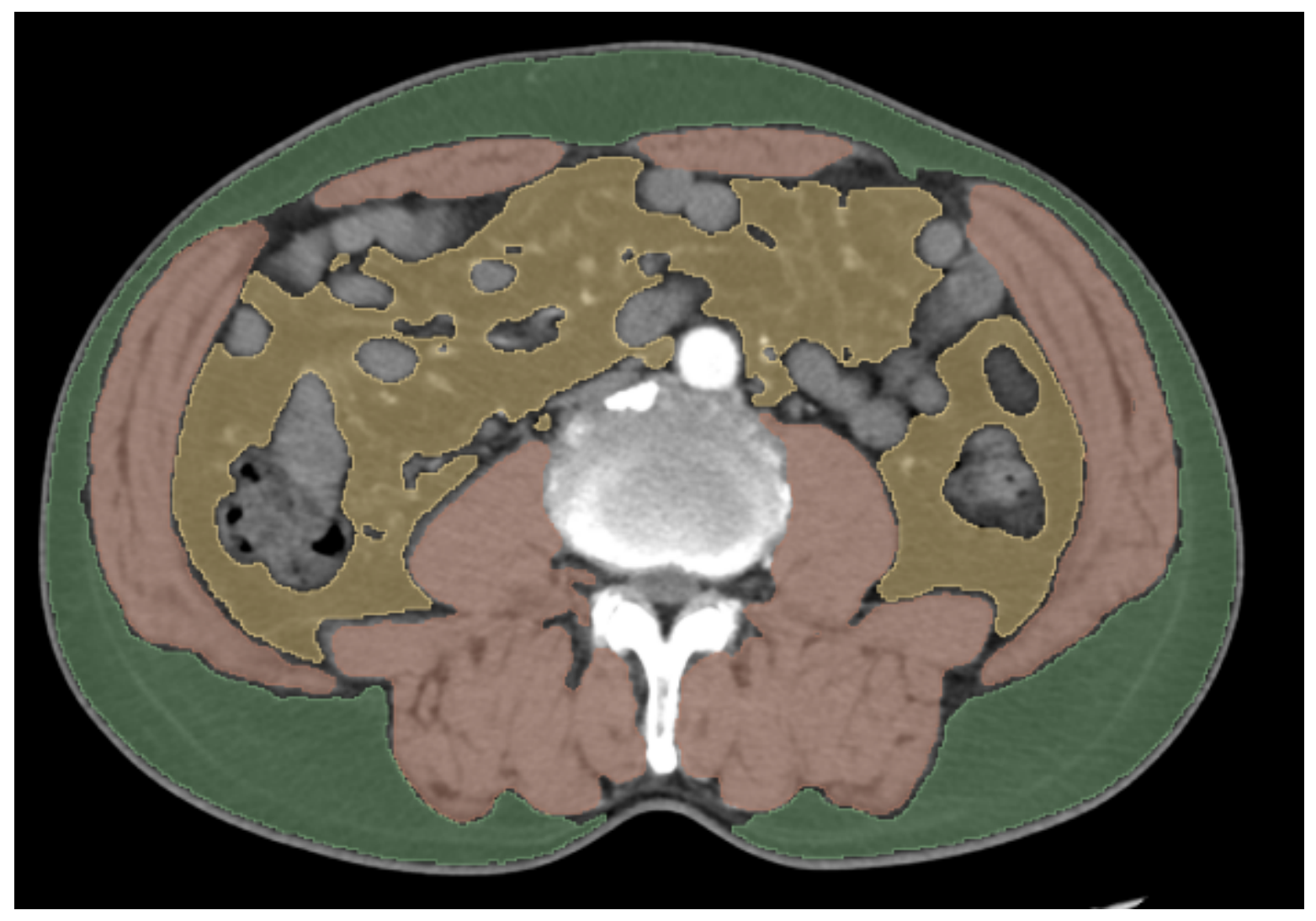

\section{Figure 1}

Body composition measurement based on CT image, areas of green, yellow and red represent subcutaneous adipose tissue, visceral adipose tissue and skeleton muscle respectively. 